\title{
THE PURSUIT OF ISOTOPIC AND MOLECULAR FIRE TRACERS IN THE POLAR ATMOSPHERE AND CRYOSPHERE ${ }^{1}$
}

\author{
L. A. CURRIE, ${ }^{2}$ J. E. DIBB, ${ }^{3}$ G. A. KLOUDA, ${ }^{2}$ B. A. BENNER, Jr., ${ }^{2} J$. M. CONNY, ${ }^{2}$ \\ S. R. BIEGALSKI, D. B. KLINEDINST, ${ }^{2}$ D. R. CAHOON ${ }^{4}$ and N. C. HSU
}

\begin{abstract}
We present an overview of recent multidisciplinary, multi-institutional efforts to identify and date major sources of combustion aerosol in the current and paleoatmospheres. The work was stimulated, in part, by an atmospheric particle "sample of opportunity" collected at Summit, Greenland in August 1994, that bore the ${ }^{14} \mathrm{C}$ imprint of biomass burning. During the summer field seasons of 1995 and 1996, we collected air filter, surface snow and snowpit samples to investigate chemical and isotopic evidence of combustion particles that had been transported from distant fires. Among the chemical tracers employed for source identification are organic acids, potassium and ammonium ions, and elemental and organic components of carbonaceous particles. Ion chromatography, performed by members of the Climate Change Research Center (University of New Hampshire), has been especially valuable in indicating periods at Summit that were likely to have been affected by the long range transport of biomass burning aerosol. Univariate and multivariate patterns of the ion concentrations in the snow and ice pinpointed surface and snowpit samples for the direct analysis of particulate (soot) carbon and carbon isotopes. The research at NIST is focusing on graphitic and polycyclic aromatic carbon, which serve as almost certain indicators of fire, and measurements of carbon isotopes, especially ${ }^{14} \mathrm{C}$, to distinguish fossil and biomass combustion sources.
\end{abstract}

Complementing the chemical and isotopic record, are direct "visual" (satellite imagery) records and less direct backtrajectory records, to indicate geographic source regions and transport paths. In this paper we illustrate the unique way in which the synthesis of the chemical, isotopic, satellite and trajectory data enhances our ability to develop the recent history of the formation and transport of soot deposited in the polar snow and ice.

\section{INTRODUCTION AND BACKGROUND}

\section{Objectives}

Combustion aerosol ("soot") is of considerable importance in atmospheric and paleoatmospheric studies because of its potential impact on radiation forcing, especially in connection with large boreal wildfires, and long range transport in polar regions of both anthropogenic, fossil fuel emissions and biomass burning emissions. Investigations of "Arctic Haze", including the use of wind trajectory analysis and elemental source signatures, showed already a decade ago that major particulate pollution reaching the pristine Arctic atmosphere in the springtime had its origins in major industrial regions of Europe and Asia. The fossil character of this material was confirmed by radiocarbon measurements of aerosol collected at Point Barrow, Alaska, where the median percentage of contemporary carbon (27\%) was comparable to typical values of soot carbon in U.S. cities (Currie 1992).

The potential impact of boreal fires is far greater. ${ }^{6}$ Periodic extreme meteorological conditions have resulted in enormous wildfires in the boreal zone, resulting in large quantities of "black (soot) carbon" that is dispersed through the Arctic region with major potential climate effects in this region of high albedo. The research we describe focuses on the investigation of current sources, transport, and

\footnotetext{
${ }^{1}$ Contribution of the National Institute of Standards and Technology; not subject to copyright.

${ }^{2}$ Chemical Science and Technology Laboratory, National Institute of Standards and Technology (NIST), Gaithersburg, Maryland 20899 USA

${ }^{3}$ Climate Change Research Center, Institute for the Study of Earth, Oceans and Space, Morse Hall, University of New Hampshire, Durham, New Hampshire 03824 USA

${ }^{4}$ Radiation Science Branch, Atmospheric Sciences Division, NASA Langley Research Center, 21 Langley Blvd., Hampton, Virginia 23681 USA

${ }^{5}$ Hughes STX, 4400 Forbes Blvd., Lanham, Maryland 20706 USA

6"Boreal" derives from the Greek mythology: Boreas, meaning the north wind. In the geographic context, Boreal originally referred to the sub-Arctic region including the large belt of coniferous forests extending from New England to Alaska. Current usage includes the large forested regions of northern China, Scandinavia, and Siberia.
}

Proceedings of the 16th International ${ }^{14} \mathrm{C}$ Conference, edited by W. G. Mook and J. van der Plicht

RADIOCARBON, Vol. 40, No. 1, 1998, P. 381-390 
scavenging of soot in the Arctic, specifically at the Greenland Ice Sheet Program GISP-2 site (Summit, Greenland $\left.\left[72.25^{\circ} \mathrm{N}, 36.40^{\circ} \mathrm{W}\right]\right)$. Complementing this work on the current atmosphere, is the extraction of the recent and paleoatmospheric (soot) records from snow pits and ice cores from the GISP-2 site. A key point of the work is that study of the current atmosphere, including transfer functions (scavenging), is essential for the interpretation of the paleoatmospheric record in ice cores (Dibb, Jaffrezo and Legrand 1992).

\section{Fire Tracers: Isotopic and Chemical Products of Incomplete Combustion}

Chemical and isotopic products of fossil and biomass combustion can serve as unique and, in certain cases, quantitative source tracers. Important categories include: 1 ) trace elements, such as $\mathrm{Pb}$ and $\mathrm{Mn}$ (motor vehicle emissions), V (oil burning), $\mathrm{K}$ (wood and other biomass burning); 2) gaseous tracers and products of combustion, such as $\mathrm{CH}_{4}, \mathrm{CO}, \mathrm{HCHO}$, and volatile organic acids, as well as $\mathrm{NH}_{3}$ and $\mathrm{H}_{2} \mathrm{O}_{2}$; and (3) gas and particulate pyrolysis and pyrosynthesis (high temperature) products such as $\mathrm{CO}$, phenolic compounds, polycyclic aromatic hydrocarbons, and elemental or "graphitic" soot carbon ("black carbon"). The latter two classes of compounds are especially interesting as fire tracers because of their association with small particles-hence, long range transport-and because of their chemical inertness. Perhaps the most interesting tracer of all is ${ }^{14} \mathrm{C}$, as it gives unique and quantitative apportionment of fossil and biomass carbon. Complementing the bulk chemical tracers are microanalytical imaging and probe techniques that can characterize individual combustion particles.

The literature on combustion particle source apportionment is vast, but useful expositions may be found in Buffle and van Leeuwen (1992). Prior data on key ionic, molecular and isotopic fire tracers in the polar atmosphere and cryosphere may be found in Dibb et al. (1996). For snow and ice cores, special importance is attached to electrical conductivity and ion chromatography data for pinpointing regions (times) of likely biomass burning impacts.

\section{The UNIQUE EVENT OF 5 AUGUST 1994}

Near the end of the 1994 field season at Summit, Greenland, atmospheric gas and ionic (surface snow) data suggested the arrival of a massive biomass burning event. Subsequent investigations of major forest fire activity and wind trajectories for that day indicated that wildfire from the Lower Hudson Bay region was the probable source (Dibb et al. 1996).

\section{Isotopic Characterization of Soot Carbon}

Unusual darkening of an air filter designed for ${ }^{7} \mathrm{Be}$ sampling led to the first ${ }^{14} \mathrm{C}$ measurements of biomass burning soot reaching Summit, Greenland. The carbon isotope served as a direct tracer for biomass carbon, showing an enhancement by nearly an order of magnitude over background levels, comparable to that of organic acids and selected ions in the surface snow (Currie et al. 1996). Changes in relative amounts of the biomass carbon (aerosol filter) and two ionic fire tracers (surface snow) during the passage of the plume over Summit are given in Table 1.

TABLE 1. Passage of the August 1994 Biomass Plume

\begin{tabular}{lccc}
\hline Date & $\begin{array}{c}\text { Ammonium } \\
\left(\mathrm{nmol} \mathrm{g}^{-1}\right)\end{array}$ & $\begin{array}{c}\text { Potassium } \\
\left(\mathrm{nmol} \mathrm{g}^{-1}\right)\end{array}$ & $\begin{array}{c}\text { Biomass carbon } \dagger \\
\left(\mu \mathrm{g} \mathrm{m}^{-1}\right)\end{array}$ \\
\hline 4 Aug. 1994 & 1.8 & 0.22 & 0.22 \\
5 Aug. 1994 & 6.8 & 0.70 & 1.6 \\
6 Aug. 1994 & 1.2 & 0.19 & 0.26 \\
\hline
\end{tabular}

*Concentrations in surface snow (Dibb et al 1996)

†Concentrations on aerosol filter (Currie et al. 1996) 
Carbon isotopes ${ }^{14} \mathrm{C}$ and ${ }^{12} \mathrm{C}$-i.e., the carbon mass-were measured also on the bracketing days, 3 and 7 August 1994, at which point the biomass carbon represented ca. $70 \%$ of the total. One might expect that this would represent an approximate upper limit for background aerosol, in the absence of a fire plume, which is relevant to our further experiments on fossil and biomass carbon in the snowpits, discussed below.

\section{Meteorology and the View from Space}

Measurement of ${ }^{14} \mathrm{C}$ has the advantage of giving direct and quantitative information on fossil/biomass carbon components, unlike the chemical tracers which must rely on indirect inference, especially those tracers that are non-carbonaceous (Currie et al. 1994). Origins of the fossil/biomass components, however, depend on indirect inference for both classes of tracers. Meteorology, in particular backtrajectory analysis, is generally used to make the link, but this field is fraught with pitfalls, especially when long-range transport and chemical reactivity are involved (Clark and Cohn 1990).

Satellite imagery has emerged as an extremely powerful complement to the isotopic-chemical and meteorological tools, and it has provided some very interesting confirmatory evidence in the case of the August 1994 event. In Figure 1 (Color Plate 2, following p. 416), we present images from two satellite systems, one focusing on the lower Hudson Bay fire source region, the other providing a telling view of Summit, Greenland - linked by up to 10-day backtrajectories from the receptor site (Summit). This rather interesting visual link between the source of biomass burning aerosol and its transport and arrival over Summit is consistent with, but quite independent of the isotopic-chemical conclusions. It also represents what might be termed a trivariate validation, i.e., the mutual validation, in this particular case, of the backtrajectory model and the high-latitude fire and smoke imagery of the respective satellites.

More complete information on the formation of the satellite images and the nature of the backtrajectory model is given in references cited below, so only a very brief description will be presented here. The fire-observing satellite is the NOAA (National Oceanic and Atmospheric Administration) advanced very high resolution radiometer (AVHRR). It utilizes different channels of long wavelength radiation to produce false color composites distinguishing among smoke plumes (orange), snow (yellow), low clouds (yellowish-white), water (blue), unburned vegetation (yellow to bluegreen) and burned forest (dark brown to black) (Cahoon et al. 1994; Justice, Kendall and Kaufman 1995; Stocks et al. 1995). The image shown is for 30 July 1994, the date on which the 5 August 1994 trajectory from Summit reached "back" to the region of numerous forest fires.

Backtrajectories were generated using the multiple layer, Hybrid Single-Particle Lagrangian Integrated Trajectories Model (HY-SPLIT) (Draxler 1992). Meteorological input, provided by the NOAA Air Resources Laboratory, consisted of a grid archive of temperature, pressure, pressure height, wind speed and humidity parameters at 6-h intervals, with a spatial resolution of $c a .180 \mathrm{~km}$. The analysis shows that the air mass arriving at Summit on 5 August 1994 passed through the heart of the fire zone on $30 \mathrm{July}$, the date of the AVHRR image.

The conclusive piece of evidence derives from the second, UV satellite image. The Total Ozone Mapping Spectrometer (TOMS) aerosol index was developed to track the long range transport of absorbing aerosol (mineral dust, combustion aerosol) over both land and water. The index, which is based on the spectral contrast between $340 \mathrm{~nm}$ and $380 \mathrm{~nm}$ backscattered radiation, has been used successfully to track smoke particles from biomass burning in South America, Africa, North America, and Asia (Hsu et al. 1996; Herman et al. 1997). The TOMS image in Figure 1 "closes the cir- 
cle," for it shows a smoke cloud directly over central Greenland on the very day the isotopic-chemical tracers of fire pointed to an intense, biomass burning event.

\section{TRANSFER OF THE ATMOSPHERIC SIGNAL TO THE SNOW}

During the 1995 and 1996 field seasons (April-July) at Summit, atmospheric (aerosol) samples were taken for isotopic and chemical characterization of combustion particles, as well as surface snow and snow collected in snowpits. The latter were of special interest in connection with the transfer of the biomass burning event of August 1994 to the cryospheric (snow, ice) archives. Because of the low concentrations generally found in remote locations, such as Summit, extreme care is required in sampling - to minimize the possibility of contamination. An illustration of the sampling operation, for the type of measurements reported in part in this paper, is given in Figure 2 (Color Plate 3, following p. 416). Here, workers, clad in the proverbial "white suits" and employing the cleanest possible tools and containers, are collecting snow from a shallow pit to obtain a depth profile of ionic concentrations covering a period of a few years.

Two sets of surface and pit snow samples were collected in 1995 and 1996. The first set is part of the ongoing atmospheric science program at the University of New Hampshire, where relatively small (ca. 30-g) samples were taken with moderately high time resolution: daily triplicates for surface snow and $3 \mathrm{~cm}$ vertical resolution for pit snow. (The time interval equivalent of $3 \mathrm{~cm}$ depends on deposition rate and depth (density), but on average, for a shallow pit it is equivalent to approximately one to three weeks. The standard uncertainties estimated from the triplicates are $c a .0 .02$ $\mathrm{nmol} \mathrm{\textrm {g } ^ { - 1 }}$ for $\mathrm{NH}_{4}$ and $0.01 \mathrm{nmol} \mathrm{g}^{-1}$ for $\mathrm{SO}_{4}$.) The second set of snow samples, designed for trace organic, microanalytic, and carbon isotopic studies by NIST, was generally smaller in number with lower time resolution. Our largest snowpit samples from the 1996 field season, for example, had a depth resolution of $12 \mathrm{~cm}$ and a snow mass of $c a .800 \mathrm{~g}$ each. Chemical patterns contained in the higher resolution ion chromatographic record gave hints of various source impacts, and provided important guidance for sample selection for the more costly trace organic and carbon isotopic analyses. Spikes in ammonium ion and sulfate concentrations are suggestive of sources of biomass and fossil combustion aerosol. Figure 3 shows these records for the past two seasons, together with the equivalent time or depth locations selected for the first, exploratory ${ }^{14} \mathrm{C}$ and $\mathrm{PAH}$ experiments at NIST.

Peaks are apparent in both surface and pit samples, with the snowpit sulfate peaks generally out of phase with those from ammonium ion. We note with interest, however, the apparent correlation $(r=0.92)$ between the ammonium and sulfate traces in the 1996 surface samples. The figures show also that the initial NIST samples were chosen to cover selected peak and baseline regions of the ammonium profile. Besides the two-variate comparison shown here, a multivariate analysis of all eight ions measured $\left(\mathrm{Na}, \mathrm{K}, \mathrm{Mg}, \mathrm{Ca}, \mathrm{Cl}, \mathrm{NH}_{4}, \mathrm{SO}_{4}, \mathrm{NO}_{3}\right)$ showed strong temporal associations between only two pairs: Ca- $\mathrm{Mg}$ (strongest) and $\mathrm{NH}_{4}-\mathrm{K}$, the latter being a presumed indicator of biomass burning aerosol. The major $\mathrm{NH}_{4}$ peaks in the 1995 and 1996 snowpits are especially interesting, for they provide a striking record of the 1994 peak fire season in both pits and the 1995 peak fire season in the 1996 snowpit.

\section{ISOTOPIC AND TRACE ORGANIC ANALYSIS OF SOOT CARBON IN THE SNOW}

Ion profiles shown in Figure 3 were used to develop our sampling plan for carbonaceous particle analysis. The specific samples taken thus far for analysis are so indicated in the figure. Analytical techniques employed included: accelerator mass spectrometry (AMS), for ${ }^{14} \mathrm{C}$; supercritical fluid 

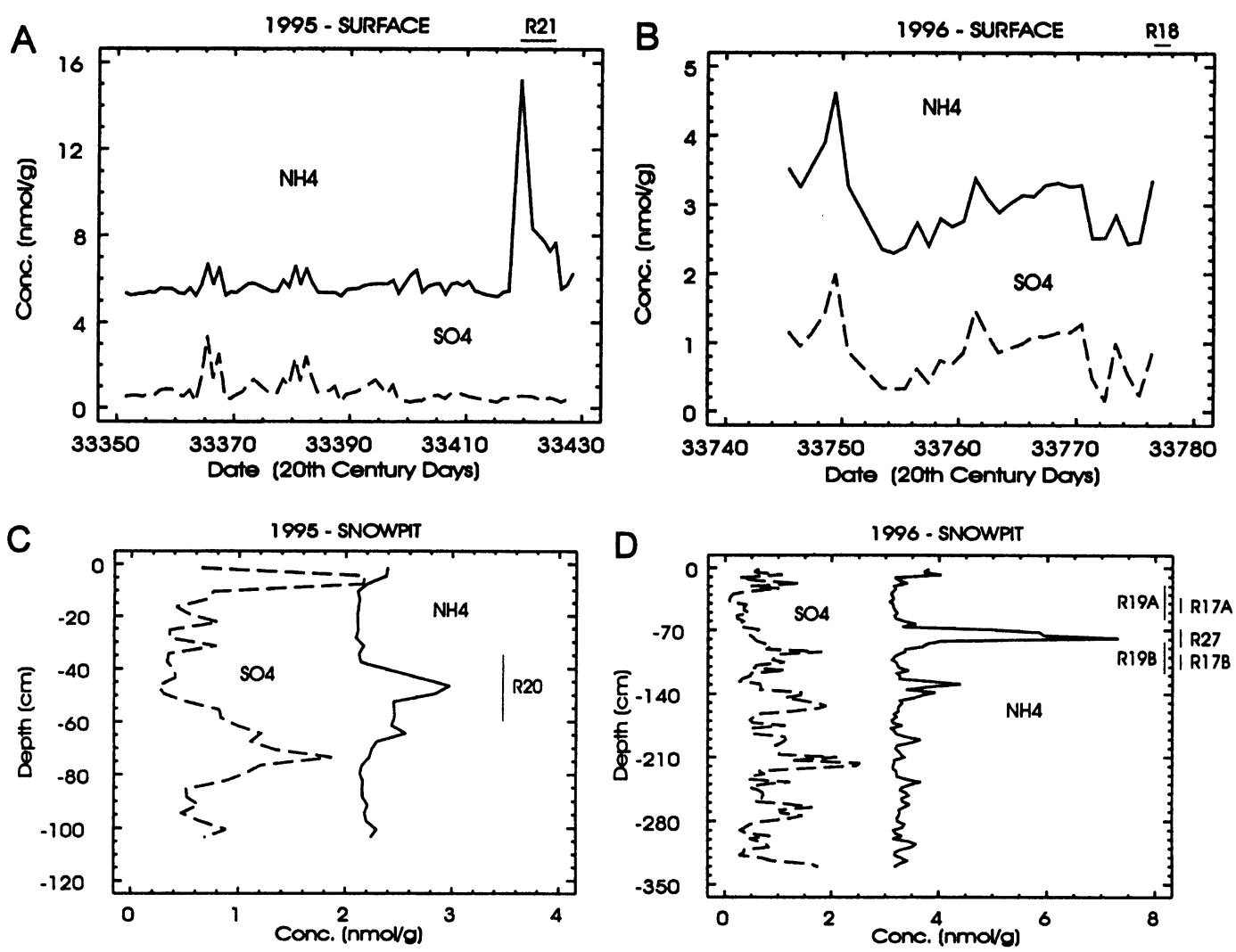

Fig. 3. A. Ammonium (solid line) and sulfate (dashed line) ion chromatography (IC) time series in the freshly deposited surface snow for the 1995 field season at Summit. B. Ammonium and sulfate surface snow data for 1996. IC sampling times (dates) are indicated on the abscissae in days since the turn of the century, corresponding to calendar dates ranging from 23 April to 9 July for 1995 , and 21 May to 21 June for 1996. Surface snow used for carbon (and ${ }^{14} \mathrm{C}$ ) analysis was collected on 30 June-5 July 1995 (R21) and 22 June 1996 (R18). Ammonium ion concentrations have been offset by $+5 \mathrm{nmol} / \mathrm{g}$ (1995) and $+2 \mathrm{nmol} / \mathrm{g}$ (1996). C. Ammonium and sulfate ion depth series in the 1995 snowpit. D. Ammonium and sulfate data for the 1996 snowpit. Ammonium ion concentrations have been offset by $+2 \mathrm{nmol} / \mathrm{g}$ (1995 snowpit) and $+3 \mathrm{nmol} / \mathrm{g}$ (1996 snowpit). The ammonium trace shows a distinctive peak for the 1994 fire season in the 1995 pit, and twin peaks for the 1994 and 1995 fire seasons in the 1996 snowpit. Also indicated are the locations (depths) for samples analyzed for ${ }^{14} \mathrm{C}$ and/or PAH (R20 (1995); R17, R19, and R27 (1996)). Note that " $A$ " and " $B$ " samples were combined for ${ }^{14} C$ analysis.

extraction gas chromatography/mass spectrometry (SFE-GC/MS), for polycyclic aromatic hydrocarbons (PAH); laser microprobe mass spectrometry (LAMMS), for carbon and elemental species at the individual particle level; and scanning as well as transmission electron microscopy (SEM, TEM), for morphological and elemental characterization of individual particles from the snow. The goals of the array of analytical methods are: 1) to characterize and quantify the insoluble combustion particles in the snow, and 2) to attempt to use the bulk and individual particle fire tracers for the identification and apportionment of the combustion sources $v s$. time and meteorology (Currie 1992). Measurements were extremely difficult because of low concentrations and limited sample sizesespecially the ${ }^{14} \mathrm{C}$ measurements, which may be the first of their kind.

Accompanying papers by Biegalski et al. (1998) and Weissenbök et al. (1998) provide details of methodology for isolating carbon and LAMMS, and AMS at the microgram level, respectively. Research involving SEM and TEM is currently underway at NIST (John Kessler, personal commu- 
nication 1997). Results of our exploratory studies of PAH, elemental and organic particulate carbon $(\mathrm{EC}, \mathrm{OC})$, and ${ }^{14} \mathrm{C}$ in insoluble particles are reported below.

\section{Elemental, Organic and Isotopic Carbon}

Elemental, or "black" carbon is a fundamental tracer for combustion in atmospheric aerosol. It, therefore, is the prime species for our efforts toward carbon quantification and ${ }^{14} \mathrm{C}$ analysis on the insoluble particulate fraction of the snow. Also relevant, and interesting for isotopic analysis, is the insoluble organic fraction of the particulate material. Data exist for the relative concentrations of these chemical fractions for a number of combustion sources, as well as for ambient urban, rural, and remote aerosol samples. Among the remote, and more specifically, Arctic air and snow samples, the elemental fraction of the particulate carbon typically ranges from roughly $10 \%$ to $40 \%$ (Cachier and Pertuisot 1994), not unlike that found in urban studies (Currie et al. 1983); and the mid-range for the concentration of elemental carbon in Greenland snow is $c a .5 \mu \mathrm{g} \mathrm{kg}^{-1}$ to $10 \mu \mathrm{g} \mathrm{kg}^{-1}$.

These data serve as a starting point for our estimation of requisite sample sizes, blank control, and AMS requirements. If we take, for estimation purposes, $25 \%$ for the relative abundance and $10 \mu \mathrm{g}$ $\mathrm{kg}^{-1}$ for the absolute abundance of elemental particulate carbon, we see that the small ( $30 \mathrm{~g}$, "high resolution") samples taken for ion chromatography would be equivalent to $\mathrm{ca} .0 .3 \mu \mathrm{g}$ elemental carbon and $0.9 \mu \mathrm{g}$ of organic particulate carbon. These are clearly at or below the current limits of contemporary (biomass burning) ${ }^{14} \mathrm{C}$ measurement by AMS (Weissenbök et al. 1998; Klinedinst et al. 1994). Then there is the chemical blank. Using the filtration-isolation and closed-tube two-stage combustion method as outlined in (Biegalski et al. 1998), we find procedural blanks in the range of ca. $2 \mu \mathrm{g}$ carbon. Thus, procedural blanks as well as current AMS capabilities for small samples mandate the recovery of at least $10 \mu \mathrm{g}$ carbon, which translates into the processing of $c a .1 \mathrm{~kg}$ of snow for adequate chemical (elemental carbon) and radiochemical $\left({ }^{14} \mathrm{C}\right)$ data. The requisite mass of snow would, of course be less for peak carbon concentrations and for organic carbon in the snow; and greater for the lowest concentrations.

A brief tabulation of data is presented in Table 2 . Note that the ${ }^{14} \mathrm{C}$ content, or more specifically the ${ }^{14} \mathrm{C} /{ }^{12} \mathrm{C}$ isotope ratio, is expressed as fraction of modern $\left(f_{M}\right)$, which is defined in terms of the ${ }^{14} \mathrm{C}$ dating standard, SRM 4990B ( $\mathrm{Kra} 1986$ ). The relation of $\mathrm{f}_{\mathrm{M}}$ to contemporary carbon and woodburning (biomass burning) carbon is presented in a glossary in Currie et al. (1989).

TABLE 2. Carbonaceous Aerosol Data from the 1995 and 1996 Snow Samples*

\begin{tabular}{|c|c|c|c|c|c|c|c|}
\hline $\begin{array}{l}\text { Sample no. } \dagger \\
\text { (depth, cm) }\end{array}$ & $\begin{array}{c}\text { Snow } \\
\text { mass } \\
(\mathrm{g})\end{array}$ & $\begin{array}{c}\text { Total } \\
\text { carbon } \\
(\mu \mathrm{g})\end{array}$ & $\begin{array}{c}\mathbf{f}_{\mathrm{M}} \\
\text { (modern) }\end{array}$ & $\begin{array}{c}\text { Organic } \\
\text { carbon } \\
(\mu g)\end{array}$ & $\begin{array}{c}f_{M} \\
\text { (modern) }\end{array}$ & $\begin{array}{c}\text { Elemental } \\
\text { carbon } \\
(\mu \mathrm{g})\end{array}$ & $\begin{array}{c}f_{M} \\
\text { (modern) }\end{array}$ \\
\hline R17A,B $(30,102)$ & 1747 & & & 133 & $0.57 \pm 0.02$ & 48 & $0.59 \pm 0.02$ \\
\hline R18 & 820 & & & 77 & $0.29 \pm 0.02$ & 31 & $0.29 \pm 0.05$ \\
\hline R19A,B $(8,108)$ & 838 & & & 179 & $0.48 \pm 0.01$ & 121 & $0.44 \pm 0.01$ \\
\hline R20 (48) & 265 & 30 & $0.41 \pm 0.04$ & & & & \\
\hline R21 & 83 & 14 & $0.46 \pm 0.10$ & & & & \\
\hline R27 (75) & 113 & & & 72 & $0.46 \pm 0.02$ & 5.4 & \\
\hline
\end{tabular}

${ }^{*} f_{M}$ values have been corrected for the isotopic-chemical blank, as well as the effect of (small) sample size on AMS efficiency (Klinedinst et al. 1994). Uncertainties in masses are less than one unit in the last digit. Combined standard uncertainties shown for the $f_{M}$ values are largely governed by the uncertainty in the blank, except for R19 (organic), where Poisson counting statistics makes a comparable contribution. (See the text and $K r a(1986)$ for definition of $f_{M}$.)

$\dagger$ Three samples were contained in 4-L jars: R17A (jar-7), R17B (jar-13), and R18 (jar-3). All others represented composites of several $(150 \mathrm{~mL}$ and $250 \mathrm{~mL})$ bottles. Mid-depths $(\mathrm{cm})$ of the snowpit samples are given in parentheses immediately following the respective sample numbers (see also Fig. 3.) 
We see that the elemental particulate carbon fraction is consistent with the literature data previously mentioned, though the absolute elemental carbon concentrations are rather larger than the midrange value used above. This is somewhat surprising, and suggests the importance of further measurements as well as a concerted effort to attack the "elemental carbon" measurement problem, perhaps by a carefully organized international comparison. For the results quoted here, "elemental" carbon was isolated by the thermal method (Biegalski et al. 1998).

The ${ }^{14} \mathrm{C}$ data, though few in number, are the first such measurements in polar snow/ice research. They indicate a range of fossil $v s$. biomass burning impacts, with the upper limit approaching the fossil/biomass carbon mix seen in the "tails" of the 5 August 1994 atmospheric aerosol plume given in Table 1. Relation of the ${ }^{14} \mathrm{C}$ content to parallel chemical data cannot be firmly established with so few samples, but an interesting correlation was seen with the sulfate data given in Figure 3, where the fraction of modern carbon showed a negative correlation with sulfate concentrations: $r=-0.7$, $p=0.04$. Such a negative correlation would be expected if the sulfate derived in part from fossil fuel combustion.

\section{Comparative Results for PAH and ${ }^{14} \mathrm{C}$}

Polycyclic aromatic hydrocarbons were analyzed in parallel snow samples using SFE-GC/MS. Because of the great sensitivity of this method, somewhat smaller samples were required, viz. $120 \mathrm{~g}$ snow. The isolation procedure consisted of snow sampling, melting and immediately filtering using prefired quartz fiber filters, as discussed in Biegalski et al. (1998). The $25-\mathrm{mm}$ quartz filters were then placed in an extraction cell, and extracted with carbon dioxide at $400 \mathrm{~atm}(40.5 \mathrm{MPa})$ and $150^{\circ} \mathrm{C}$ for a 10 -min static, and a $10-$ min dynamic extraction. During the dynamic SFE, the extracts were transferred to a GC column at $-30^{\circ} \mathrm{C}$. After the dynamic SFE the column was heated rapidly to $30^{\circ} \mathrm{C}$ and then to $310^{\circ} \mathrm{C}$ at $4^{\circ} \mathrm{C}$ per minute. Selective ion mass spectral monitoring was applied for determining PAH-specific ions.

The resulting reconstructed ion chromatograms for the two samples processed are shown in Figure 4; comparative quantitative data are given in Table 3. (The sampling depths in the 1996 Summit snowpit are indicated in Fig. 3D.) PAH peaks benzo(e)pyrene and benzo(ghi)perylene shown in Fig-

TABLE 3. Comparative PAH and ${ }^{14} \mathrm{C}$ Data-1996 Snowpit*

\begin{tabular}{lccc}
\hline PAH & $\begin{array}{c}\text { Sample R17A } \\
(120 \mathrm{~g} \text { snow })\end{array}$ & $\begin{array}{c}\text { Sample R17B } \\
(120 \mathrm{~g} \text { snow) }\end{array}$ & $\begin{array}{c}\text { Urban sample } \\
\text { (air filter) }\end{array}$ \\
\hline Retene & $\begin{array}{r}8 \mathrm{pg} \\
\text { Benzo(e)pyrene }\end{array}$ & $\begin{array}{r}10 \mathrm{pg} \\
23 \mathrm{pg}\end{array}$ & \\
$\begin{array}{l}\text { Benzo(ghi)perylene } \\
\text { Retene/ }\end{array}$ & $\begin{array}{r}12 \mathrm{pg} \\
\text { benzo(e)pyrene }\end{array}$ & $\begin{array}{r}18 \mathrm{pg} \\
0.43\end{array}$ & 0.15 \\
$\begin{array}{l}\text { Benzo(e)pyrene/ } \\
\text { benzo(ghi)perylene }\end{array}$ & 1.33 & 1.28 & 0.56 \\
\hline \hline${ }^{14} \mathrm{C}(1747$ g snow) & $\begin{array}{l}\text { Organic-C } \\
(\mathrm{R} 17 \mathrm{~A}+\mathrm{B})\end{array}$ & $\begin{array}{l}\text { Elemental-C } \\
(\mathrm{R} 17 \mathrm{~A}+\mathrm{B})\end{array}$ & $\begin{array}{l}\text { Total-C } \\
\text { (urban sample) }\end{array}$ \\
\hline $\mathrm{f}_{\mathrm{M}}$ & $0.57 \pm 0.02$ & $0.59 \pm 0.02$ & $0.19 \pm 0.01$ \\
\hline
\end{tabular}

*Snowpit PAH data were derived from $120 \mathrm{~g}$ aliquots of samples R17A (jar-7) and R17B (jar-13). Snowpit ${ }^{14} \mathrm{C}$ data were obtained from the remaining $1747 \mathrm{~g}$ of the combined (R17A+B) samples. Urban data were obtained from portions of an air filter ("Gates: 921208") used in an urban air pollution study in 1992 (Klinedinst et al. 1997). Relative standard uncertainties for the PAH data are ca. $10 \%$. 


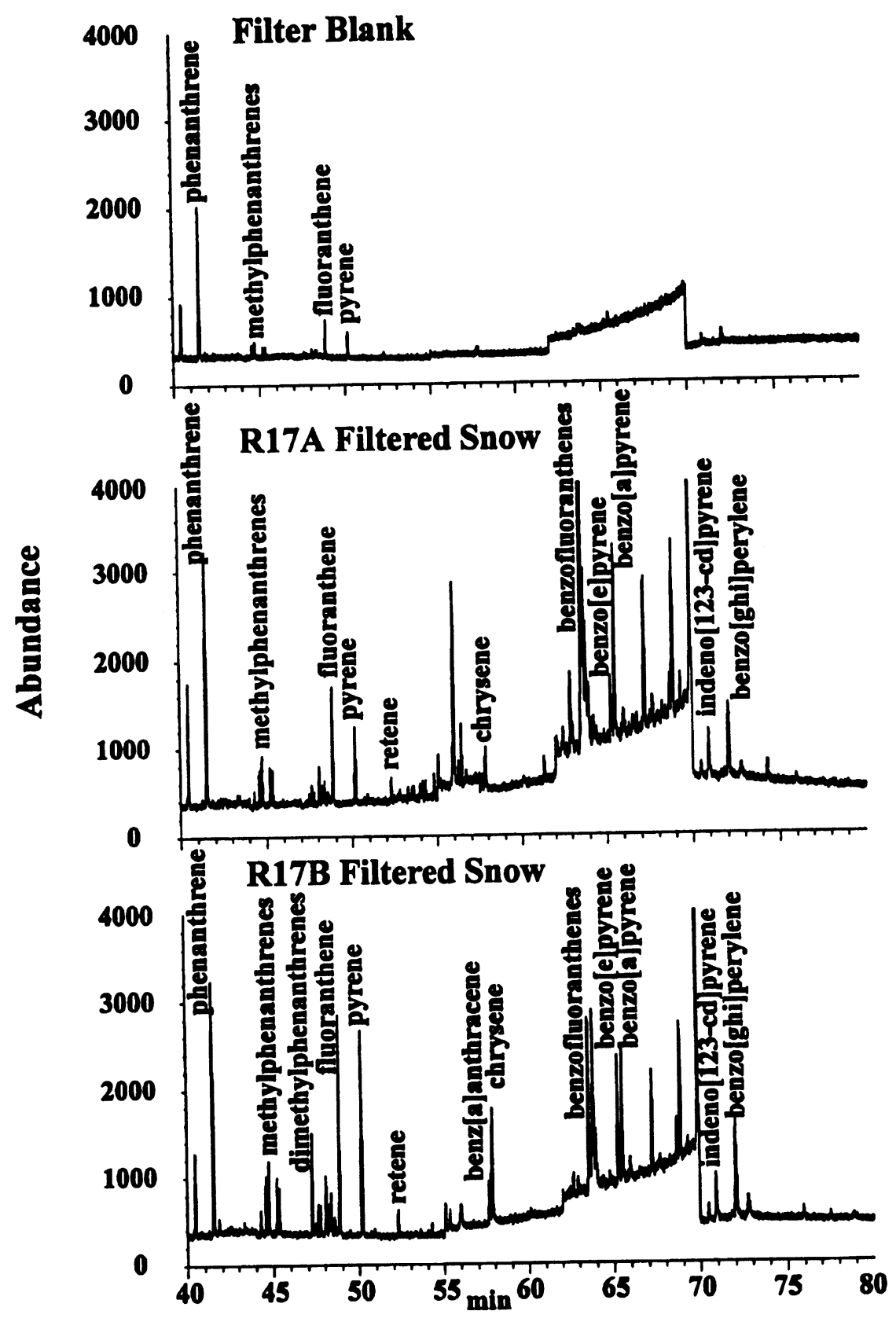

Fig. 4. Online supercritical fluid extraction-gas chromatography/mass spectrometry (SFE-GC/MS) of particles from Greenland snow. Samples R17A and R17B are from the 1996 Summit snowpit (see Fig. 3D).

ure 4 may be taken as approximate measures of total combustion PAH and fossil fuel combustion PAH, respectively (Buffle and van Leeuwen 1992; Currie et al. 1994). Their ratio, therefore, serves as an index for the relative biomass/fossil contributions to the soot carbon. The comparative sample labeled "Urban" comes from a recently completed study of fossil/biomass combustion aerosol in a United States city (Klinedinst, Kenniston and Klouda 1997). A consistent story evolves from both 
of the biomass/fossil carbon indicators in Table 3, namely the molecular ratio benzo(e)pyrene/ benzo(ghi)perylene, and the isotopic ratio ${ }^{14} \mathrm{C} /{ }^{12} \mathrm{C}$, when we compare the urban soot sample to that scavenged by the Greenland snow. Further support comes from the ratio of lower molecular weight $\mathrm{PAH}$ to benzo(e)pyrene generally, and the relative abundance of the conifer pyrolysis product retene. As shown in the table, the ratio (retene/benzo(e)pyrene) in the snowpit samples is about three times as large as in the urban sample. Thus, for these comparative samples, the relatively greater biomass carbon fraction in the snowpit soot sample, compared to the urban atmospheric soot sample, gets mutual support from both of the molecular PAH ratios as well as the isotopic $\left({ }^{14} \mathrm{C} /{ }^{12} \mathrm{C}\right)$ ratio for biomass and fossil combustion aerosol tracers.

\section{ConClusion}

A multifaceted study of the origin, transport, and deposition of biomass burning carbonaceous aerosol in the Arctic has been completed. It is unique in two important respects: 1) The study includes the very first linkage of IR and UV satellite imagery with backtrajectory analysis plus indirect chemical and direct isotopic measures of the biomass contributions to the transported aerosol; 2) the study includes also the first measurements of ${ }^{14} \mathrm{C}$ soot carbon to be made in polar snow or ice. The "visual" and meteorological tracking of the biomass burning aerosol to Summit, Greenland served as a means for mutual validation of both the backtrajectory modeling and the satellite imagery modeling, and both were consistent with the fire tracer data at the receptor location (Summit, Greenland). The ${ }^{14} \mathrm{C}$ data showed a significant biomass burning contribution in recent snow cores, consistent with major biomass burning contributions to the atmospheric aerosol during peak summer fire seasons. Observations of PAH patterns in the (aerosol) snow core "archives" reinforced the ${ }^{14} \mathrm{C}$ data, reflecting a higher biomass carbon contribution compared to a typical urban aerosol sample. Apparent anticorrelation of ${ }^{14} \mathrm{C}$ with sulfate in the snow suggested changing impacts of sulfate-related fossil carbon aerosol. Finally, the research represents a major challenge for elemental carbon and elemental carbon- ${ }^{14} \mathrm{C}$ assay, because of the low concentrations in such remote samples. The potential impact of such research on our knowledge of the history of fossil and biomass burning on the regional/hemispheric scale is considerable, as is the relationship to climate forcing resulting from radiation absorption and albedo effects of the black, soot carbon.

\section{ACKNOWLEDGMENTS}

Partial support for this work came from NASA contract W-18959 with NIST (LAC), an NRC Postdoctoral Fellowship at NIST (SRB), and NSF OPP grant 9223988 to UNH (JED). Timely efforts by the staff of the NSF AMS facility at the University of Arizona to provide ${ }^{14} \mathrm{C}$ data are gratefully acknowledged, as is the assistance of Julie VanValkenburgh in certain phases of the AMS target production. We offer special acknowledgment to Anne Thompson and Jay Herman of the Laboratory for Atmospheres, NASA Goddard Space Flight Center, for important discussion and insight concerning the smoke and dust tracking capabilities of the Total Ozone Mapping Spectrometer. We thank Mark Twickler of the Climate Change Research Center, University of New Hampshire, for the photograph of the snowpit sampling operation (Fig. 2).

\section{REFERENCES}

Biegalski, S. R., Currie, L. A., Fletcher, R. A., Klouda, G. A. and Weissenbök, R. 1998 AMS and microprobe analysis of combusted particles in ice and snow. $R a$ diocarbon, this issue.

Buffle, J. and van Leeuwen, H. P., eds. 1992 IUPAC En- vironmental Analytical Chemistry Series, Vol. 1. Lewis Publishers, Inc.

Cachier, H. and Pertuisot, M. H. 1994 Particulate carbon in Arctic ice. Analusis 22: 34-37.

Cahoon, D. R. Jr., Stocks, B. J., Levine, J. S., Cofer, 
W.R., III and Pierson, J. 1994 Satellite analysis of the severe 1987 forest fires in northern China and southwestern Siberia. Journal of Geophysical Research 99: 18627-18638.

Clark, T. L. and Cohn, R. D. 1990 Across North America Tracer Experiment. USEPA Report 600/3-90/051.

Currie, L. A. 1992 Source apportionment of atmospheric particles. In Buffle, J. and van Leeuwen, H. P., eds., Characterization of Environmental Particles Vol. I. IUPAC Environmental Analytical Chemistry Series. Lewis Publishers, Inc.: 3-74.

Currie, L. A., Benner, B. A., Jr., Klouda, G. A., Conny, J. M. and Dibb, J. E. (abstract) 1996 Tracking biomass burning aerosol: From the combustion laboratory to Summit, Greenland. Workshop on Global Climate Change. Radiocarbon 38(1): 20.

Currie, L. A., Klouda, G. A., Continetti, R. E., Kaplan, I. R., Wong, W. W., Dzubay, T. G. and Stevens, R. K. 1983 On the origin of carbonaceous particles in American cities: Results of radiocarbon "dating" and chemical characterization. In Stuiver, M. and Kra, R. S., eds., Proceedings of the 11 th International ${ }^{14} \mathrm{C}$ Conference. Radiocarbon 25(2): 603-614.

Currie, L. A., Stafford, T. W., Sheffield, A. E., Klouda, G. A., Wise, S. A. and Fletcher, R. A. 1989 Microchemical and molecular dating. In Long, A., Kra, R. S. and Srdoc, D., eds., Proceedings of the 13th International ${ }^{14} \mathrm{C}$ Conference. Radiocarbon 31(3): 448-463.

Currie, L. A., Sheffield A .E., Riederer, G. E. and Gordon, G. E. 1994 Improved atmospheric understanding through exploratory data analysis and complementary modeling: The urban $\mathrm{K}-\mathrm{Pb}-\mathrm{C}$ system. Atmospheric Environment 28: 1359-1369.

Dibb, J. E., Jaffrezo, J.-L. and Legrand, M. 1992 Initial findings of recent investigation of air-snow relationships in the Summit region of Greenland. Journal of Atmospheric Chemistry 14: 167-180.

Dibb, J. E., Talbot, R. W., Whitlow, S. I., Shipham, M. C., Winterle, J., McConnell, J. and Bales, R. 1996 Biomass burning signatures in the atmosphere and snow at Summit, Greenland: An event on 5 August 1994. Atmospheric Environment 30: 553-561.

Draxler, R. R. 1992 Hybrid single-particle Lagrangian integrated trajectories (HY-SPLIT): Version 3.0, User's guide and model description. NOAA Technical
Memorandum ERL ARL-195.

Herman, J. R., Bhartia, P. K., Torres, O., Hsu, C., Seftor, C. J. and Celarier, E. 1997 Global distribution of UVabsorbing aerosols from Nimbus 7/TOMS data. Journal of Geophysical Research 102: 16911-16922.

Hsu, N. C., Herman, J. R., Bhartia, P. K., Seftor, C. J., Torres, O., Thompson, A. M., Gleason, J. F., Eck, T. F. and Holben, B. N. 1996 Detection of biomass burning smoke from TOMS measurements. Geophysical Research Letters 23: 745-748.

Justice, C. O., Kendall, J. D. and Kaufman, Y. J. 1995 (ms.) Global fire mapping using satellite data: An overview. Paper presented at the Chapman Conference on Biomass Burning and Global Change, Williamsburg, Virginia, March 1995.

Klinedinst, D. B., Kenniston, G. E. and Klouda, G. A. (ms.) 1997 Evaluation of the residential woodburning contribution to $\mathrm{PM}_{10}$ carbon in Denver, Colorado using radiocarbon analysis. To be submitted to Environmental Science and Technology.

Klinedinst, D. B., McNichol, A. P., Currie, L. A., Schneider, R. J., Klouda, G. A., von Reden, K. F., Verkouteren, R. M. and Jones, G. A. 1994 Comparative study of $\mathrm{Fe}-\mathrm{C}$ bead and graphite target performance with the National Ocean Science AMS (NOSAMS) facility recombinator ion source. Nuclear Instruments and Methods in Physics Research B92: 166-171.

Kra, R. 1986 Standardizing procedures for collecting, submitting, recording, and reporting radiocarbon samples. In Stuiver, M. and Kra, R., eds., Proceedings of the 12 th International ${ }^{14} \mathrm{C}$ Conference. Radiocarbon 28(2A): 765-775.

Stocks, B. J., Cahoon, D. R., Goldammer, J. G. and Bauer, R. J. (ms.) 1995 Documenting the seasonal distribution of vegetation fires using DMSP and NOAAAVHRR satellite imagery. Paper presented at the Chapman Conference on Biomass Burning and Global Change, Williamsburg, Virginia, March 1995.

Weissenbök, R., Biegalski, S. R., Currie, L. A., Klinedinst D. B., Golser, R., Klouda, G. A., Kutschera, W., Priller, A. Rom, W., Steier, P. and Wild, E. $1998{ }^{14} \mathrm{C}$ measurements of sub-milligram carbon samples from aerosols. Radiocarbon, this issue.

Note added in proofs: Although the carbon isolation procedure for LAMMS was outlined in Biegalski et al. (1998), the filtration isolation, two-stage combustion procedure (applied to samples R17-R19) was not. That procedure started with triple filtration of the meltwater, using prefired $25 \mathrm{~mm}$ quartz filters. The filters were then covered with prefired $\mathrm{Al}$ foil and placed in an oven at $110^{\circ} \mathrm{C}$ for $3 \mathrm{~h}$. The final steps consisted of two-stage, closed-tube oxidation and $\mathrm{CO}_{2}$ trapping: stage 1 used 33.7 mbar $\left(3.4 \mathrm{kPa}\right.$ ) of oxygen at $340^{\circ} \mathrm{C}$ for $2 \mathrm{~h}$; stage 2 used $\mathrm{CuO}$ (with $\mathrm{Ag}$ wire) at $900^{\circ} \mathrm{C}$ for $3 \mathrm{~h} . \mathrm{CO}_{2}$ was trapped and quantified by manometry following each stage. The first stage was omitted for ${ }^{14} \mathrm{C}$ measurements of total carbon. 